\title{
DAŇOVÝ SYSTÉM A DAŇOVÝ MIX V ČESKÉ REPUBLICE
}

\author{
Monika Pavlíková
}

\section{Klíčová slova:}

daňový mix, daňový systém, daňová reforma, daňová politika, osobní důchodová daň

\section{Key words:}

tax mix, tax system, tax reform, tax policy, personal income tax

\begin{abstract}
Abstrakt
Článek se zabývá vývojem daňového systému a daňového mixu v České republice. Nejprve poukazuje na výrazný vliv těchto obecně známých pojmů na ekonomickou realitu. A to v té míře, že daňový systém ovlivňuje negativní jevy ve společnosti, dále také podněcuje ekonomický růst při dobře zvolené daňové politice. Následně tento článek dává historický nástin daňových reforem, které byly provedeny na území našeho státu. A také vývoj daňového mixu, tedy jednotlivé daně a kvazidaně, jak se vyvíjely v průběhu času a jaký měly dopad na naši společnost.
\end{abstract}

\begin{abstract}
This article deals with the development of tax system and tax mix in the Czech Republic, the following points will be reviewed how significant influence of these well-known concepts to economic reality and how to the extent that the tax system affects the negative phenomena in society, as well as stimulating economic growth at well-chosen tax policy. Consequently, this article gives a historical outline of tax reforms that have been made in our country. The development of the tax mix, thus the individual taxes and quasi-taxes, as they have been developed over time and how they have impacted on our society.
\end{abstract}

\section{Úvod}

Rakouský politik F. W. Haugwitz v minulosti prohlásil, že “duší státu je dobře zorganizované finanční direktorium", měl tím na mysli, že bez dobře uspořádaného daňového systému nemůže stát fungovat.

Názory na zásady zdanění se mezi specialisty i veřejností v mnohém různí. Dalo by se říci, že někteří preferují přerozdělovací funkci, jiní ji odmítají a kladou důraz na neutralitu daňového systému. Existují ještě další požadavky na daně, jako makroekonomické funkce, stimulační funkce nebo jednoduchost a levnost. Je jisté, že skloubit všechny zdaleka není možné. Záleží však na prioritách toho, kdo o konkrétní podobě daní rozhoduje.

Tento článek pojednává o daňovém systému v pohledu jeho rozsáhlosti, resp. co všechno v sobě zahrnuje. Také se zabývá daňovou politikou jako jednou z oblastí hospodářské politiky, jež může současně účinně ovlivňovat chování poplatníků požadovaným směrem. Určitě je žádoucí zdůraznit historický exkurz v podobě daňových reforem, které byly provedeny na území České republiky a jejich ovlivnění naší hospodářské reality. Následně je věnován prostor pro daňový mix pro oblast našeho státu. Jak se tento daňový mix vyvíjel v proudu času, jelikož každý moderní daňový systém chce mít rozložení daňového mixu co nejefektivnější. Celkově článek je zpracován s využitím vědeckých metod práce, jako jsou analýza, syntéza, dedukce a komparace. 


\section{Daňový systém v České republice}

Téměř žádná jiná oblast hospodářské politiky není tak mediálně atraktivní a tolik spjatá př́ímo s politikou jako takovou, jako veřejné finance, tedy i daňová politika. Téma veřejných př́jmů, veřejných výdajů a politických procesů, které s nimi tak či onak souvisí, je natolik rozsáhlé, že se mu i dnes již věnuje několik samostatných odvětví ekonomie - např́klad daňová teorie, ekonomie blahobytu a další. To není jistě překvapivé, když si uvědomíme, do jakého rozměru veřejný sektor během dvacátého století ve vyspělých zemích narostl. ${ }^{1}$

Daňová politika je základní součástí fiskální, resp. celkové hospodářské politiky státu a naplňuje $\mathrm{v}$ aktivitách státu řadu podstatných rolí. Dalo by se říci, že je silným nástrojem vlády, který je používán k ovlivňování ekonomického růstu, je zdrojem přerozdělování důchodů ve společnosti a současně je účinným prostředkem ovlivňování chování poplatníků žádoucím směrem. Zejména před volbami, kdy různé politické strany slibují další slevy na daních, snížení daňových sazeb a další úpravy týkající se této problematiky. Různé politické či ekonomické ideologie a skupiny se liší pohledem na funkce státu ve společnosti a objevují se i diferencované pohledy na intenzitu a množství státních intervencí a zásahů do tržního mechanismu. Avšak bez ohledu na názorovou pestrost je neadekvátní daňová politika a fiskální politika státu schopna podněcovat růst negativních jevů od poklesu ekonomické aktivity přes prohloubení deficitu veřejných financí až po narušení sociálního konsensu ve společnosti.

Následující graf jasně ukazuje na základě komparace dat vývoj státního dluhu na území našeho státu během posledních šesti let. Je evidentní, že celkově státní dluh neustále roste, což bylo a je zapř́ččněno neadekvátní daňovou (hospodářskou) politikou, kdy docházelo $\mathrm{k}$ opakovaným deficitním rozpočtům vlády a dále pak převzetím části dluhu při dělení Československa. V minulém roce 2010 činil státní dluh vyjádřený z hrubého národního produktu $38,5 \% .^{2}$

Graf 1 Vývoj státního dluhu (v mld.)

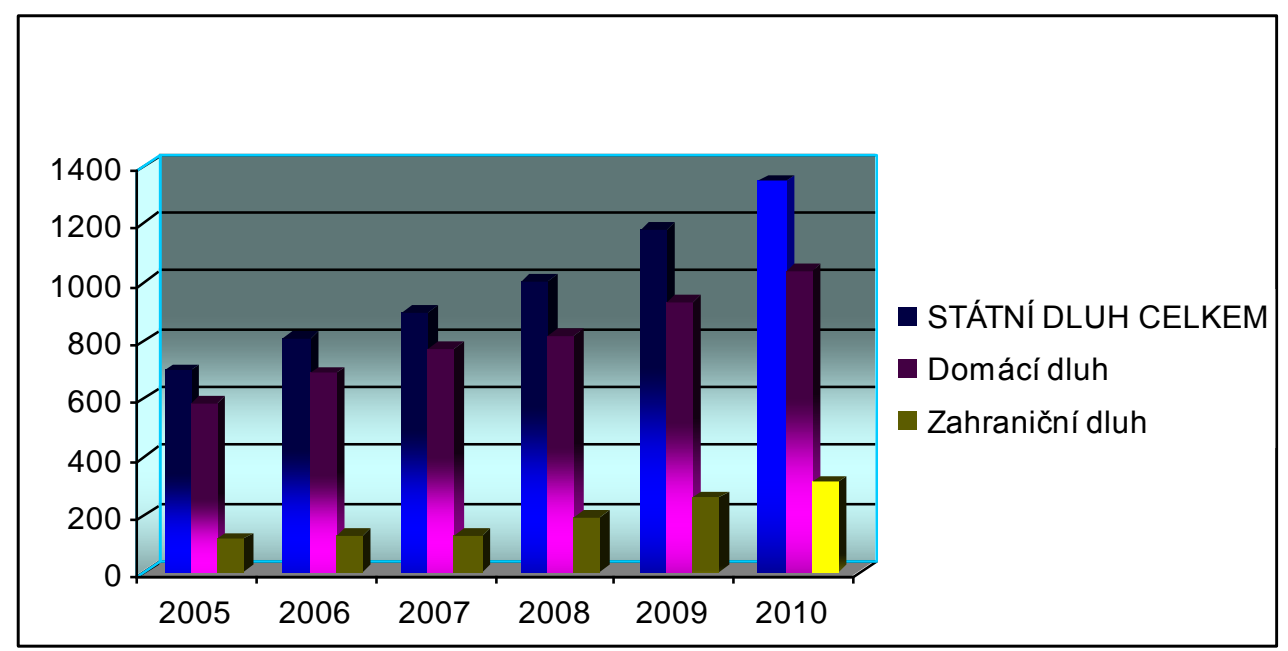

Pramen: Vývoj státního dluhu (v mld.). Vlastní zpracování na základě dat získaných z WWW: <http://www.mfcr.cz/cps/rde/xchg/mfcr/xsl/str_vyvoj_sd.html>. [online]. [cit. 2011-04-20].

\footnotetext{
${ }^{1}$ KUBÍČEK, J. A KOL. Hospodářská politika, s. 36.

${ }^{2}$ Eurostat. Dostupné na WWW: <http://epp.eurostat.ec.europa.eu>. [online]. [cit. 2011-04-22].
} 
Prostřednictvím daní jsou financovány veřejné výdaje, které slouží k zajištění hospodářského růstu a životní úrovně obyvatel. Přitom není rozhodující jen výše daní, ale i struktura daňového břemene, konstrukce daňového základu a s tím spojené náklady. $K$ růstu efektivity zdanění se zpravidla doporučuje široký základ a nízká sazba, přesun břemene z přímých daní na nepř́mé daně a snižování progresivity zdanění fyzických osob.

Je nutné podotknout, že jednotlivé země nepoužívají k naplnění státních rozpočtů samozřejmě jen jednu daň, ale několik daní, které jsou více či méně důležité, ale každá z nich plní svou určitou roli. A tak kombinace více daní, umožňuje plnění jednotlivých funkcí daní. Tedy daňová soustava představuje souhrn všech daní, které se na daném území vybírají.

Obecně je nutno zdůraznit, že daňové př́ijmy jsou nejvýznamnějším a největším finančním př́ijmem veřejného rozpočtu a podílejí se na jeho tvorbě téměř devadesáti procenty. Následující graf ukazuje podíl jednotlivých daní (kromě pojistného) na daňových př́imech státního rozpočtu v roce 2010.

Graf 2 Podíl jednotlivých daní na daňových př́ijmech státního rozpočtu v roce 2010

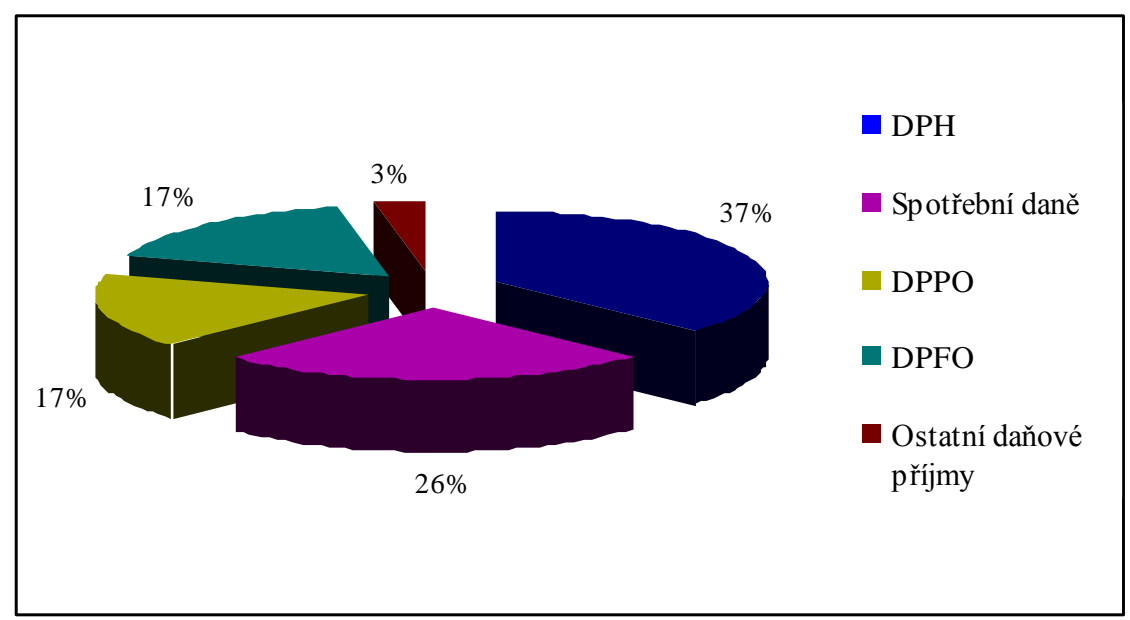

Pramen: Podíl jednotlivých daní na daňových př́ijmech státního rozpočtu v roce 2010. Vlastní zpracování na základě dat získaných z WWW: <http://www.mfcr.cz/cps/rde/xchg/mfcr/xsl/statni_zav_ucet_62819.html?year= PRESENT>. [online]. [cit. 2011-04-29].

Jak je možno z grafu vypozorovat, v kontextu vývoje největší podíl na daňových př́imech má v minulém roce daň $\mathrm{z}$ přidané hodnoty (DPH) a to celými $37 \%$, tedy více než jedna třetina. Následují spotřební daně a to s $26 \%$ a třetí v podstatě i čtvrté pomyslné místo drží daně z prríjmů fyzických či právnických osob, shodně se $17 \%$. Nejmenší podíl v roce 2010 měly ostatní daňové př́íjmy s jen $3 \mathrm{mi} \%$.

Daňový systém je širším pojmem. Lze pod ním chápat nejen daňovou soustavu, ale celý systém právních organizačně technických a kontrolních institucí, které zajišt'ují tvorbu legislativy, správu daní, kontrolu a vymáhání. Jedná se o systém nástrojů a metod, které instituce využívají ve vztahu k daňovým subjektům. ${ }^{3}$

\footnotetext{
${ }^{3}$ JANOUŠKOVÁ, J. Daně a daňová politika, s. 15.
} 
Obrázek 1 Daňová soustava České republiky

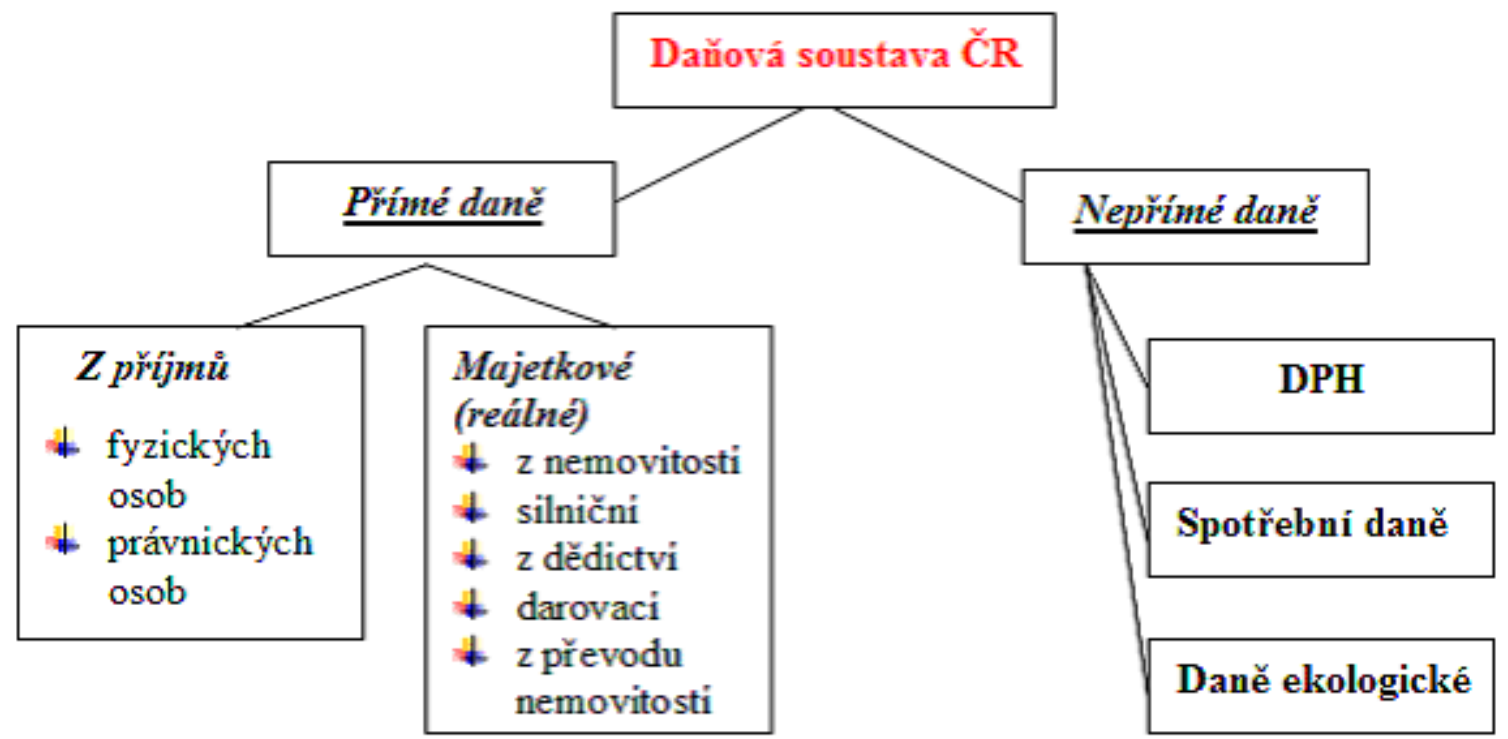

Pramen: Daňová soustava ČR. Vlastní zpracování na základě informací získaných z WWW:

<http://www.mfcr.cz/cps/rde/xchg/ mfcr/xsl/zakony.html>. [online]. [cit. 2011-05-01].

\subsection{Historie daňových reforem v České republice}

Od roku 1993 po rozdělení Československa docházelo ke změnám daňové legislativy ve stovkách případů, za daňové reformy lze alespoň do určité míry považovat pouze následující etapy vývoje:

Období let 1991 až 1993 - Zavedení standardního daňového systému tržní ekonomiky, Období let 2003 a 2004 - Implementace legislativy Evropské unie,

Období let 2005 a 2006 - Změna daňové incidence - zvýšení progresivity daňového systému, Rok 2008: Rychlá fáze přizpůsobení daňového systému v rámci konsolidace veřejných rozpočtů,

Období let 2009 a 2010 a dále - Modernizace daňového systému (nové zákony o př́mých daních). ${ }^{4}$

\section{Období let 1991 až 1993 - Zavedení standardního daňového systému tržní ekonomiky}

Podle A. Vančurové není žádných pochyb o tom, že se jednalo o zcela zásadní daňovou reformu, pokud ovšem je možno za daňovou reformu považovat pohyb ze stavu nula, kdy daňový systém neexistuje do stavu, kdy je konstituován. Je užitečné si připomenout, jak byly definovány cíle reformy, a tom tím spíše, že v současné době některé z nich už zcela vymizely:

Zásadním krokem, který předvídal pozdější vstup České republiky do Evropské unie a rovněž reagoval na daňové podmínky v oblasti nepřímých daní v celé západní Evropě, bylo zavedení daně z přidané hodnoty spotřebních daní v roce 1993.

\footnotetext{
${ }^{4}$ VANČUROVÁ, A. Daňové reformy ČR In. Teoretické a praktické aspekty veřejných financí, s. 292.
} 
Posun $\mathrm{k}$ daňovému prostředí obvyklému $\mathrm{v}$ evropských zemích bylo rovněž oddělení sociálního pojistného od daní z př́ijmů. Je třeba zaznamenat, že $\mathrm{v}$ padesátých letech minulého století bylo sociální pojistné zaměstnanců integrováno do daně ze mzdy.

Cílem, reagujícím na patologický jev soustavy veřejných př́imů socialistického Československa, bylo sjednocení zdanění všech forem podnikatelských subjektů na straně jedné a jednotlivců na straně druhé.

Nejen reakcí na vysoké odvodové zatížení zisku podniků ale i na potřebu transformující se ekonomiky přilákat zahraniční kapitál byl cíl snižit význam zdanění důchodů právnických osob, tj. efektivní daňovou sazbu.

Tento cíl byl realizován zejména snížením nominální sazby daně, avšak při současném rozšírení základu daně. Ačkoli cílem bylo rovněž posílení postavení osobní důchodové daně a vertikální daňové spravedlnosti, daň z př́ijmů fyzických osob byla nastavena tak, že její podíl $\mathrm{v}$ daňovém mixu byl pod průměrem nejen v Evropě ale i v OECD. ${ }^{5}$

Progresivita sazby daně z př́ijmů fyzických osob byla relativně vysoká oproti výchozímu stavu, od té doby se z hlediska nominální sazby až do roku 2005 stále snižovala.

Mezi evergreeny v oblasti cílů daňových reforem pak patří omezení prostoru pro vyhýbání se zdanění a daňové úniky stejně jako zefektivnění daňové správy. Stanovené cíle byly naplněny s výjimkou posledních dvou, avšak výsledkem byl daňový systém, který měl opravdu velmi daleko do právní perfektnosti. Daňové zákony byly opakovaně novelizovány již v roce 1993, a to v řadě prrípadů se zpětnou účinností.

\section{Obdobi let 2003 a 2004 - Implementace legislativy Evropské unie}

Příkladem daňové reformy vyvolané vnějším prostředím je ta, která byla vyvolaná vstupem České republiky do Evropské unie a nutností implementace komunitárního práva. Výsledkem byl především nový zákon o dani z prridané hodnoty a nový zákon o spotřebních daních. Skok způsobený díky implementaci komunitárního práva byl však zmírněn díky vyjednaným výjimkám, jejich platnost doznívala řadu let. Uvedené změny byly využity i pro zvýšení výnosu nepř́mých daní, a to nejen díky zvýšení sazeb spotřebních daní, ale i podstatným zúžením položek podléhajícím snížené sazbě daně z přidané hodnoty.

Vyčištění položek pro sníženou sazbu šlo daleko nad požadavky směrnic Evropské unie. Současně byla nastartována implementace daňových principů v oblasti přesunu kapitálu mezi státy Evropské unie, týkající se především daně z př́ijmů právnických osob.

\section{Období let 2005 a 2006 - Změna daňové incidence - zvýšení progresivity daňového systému}

Je sporné, zda změny ve zdanění v letech 2005 a 2006 je možno považovat za daňovou reformu, nebot' se týkaly skoro především daně z př́ijmů fyzických osob. Šlo o dvojfázový přechod od sociálních standardních odpočtů ke slevám na dani z př́ijmů fyzických osob, zavedení daňového bonusu, změna úrovní nominální sazby daně z př́ijmů fyzických osob. Nerealizovaným zůstal $v$ těchto letech záměr zavedení všeobecného maximálního vyměřovacího základu pojistného sociálního pojištění.

\footnotetext{
${ }^{5}$ OECD. Dostupné na WWW: <http://www.mfcr.cz/cps/rde/xchg/mfcr/xsl/meo_oecd.html>. [online]. [cit. 201105-04].
} 
Rok 2008: Rychlá fáze přizpůsobení daňového systému v rámci konsolidace veřejných rozpočtù

Po zásadní změně vládní koalice v roce 2007 byl nastartován proces konsolidace veřejných financí, které v prvé rychlé fázi se projevil především v reformě daňové, ačkoliv by bylo zřejmě potřebnější začít od výdajové reformy, ale ochota významně omezit transfery obyvatelstvu, a to včetně nejen mírně parametrické důchodové reformy zatím nenastala.

V oblasti daňového systému se tato reforma projevila především:

- Snížení nominální sazby daně z příjmů právnických osob bylo téměř kompenzováno rozšířením základu daně (nejspornější je podstatné zpřísnění pravidel podkapitalizace, která se př́liš nepovedla pro jejich složitost a nejednoznačnost),

- Zavedení principu zdanění „superhrubé“ mzdy, které je z právního hlediska sporné, protože sociální pojistné hrazené zaměstnavatelem lze jen velmi těžko z právního hlediska považovat za př́jem zaměstnance, a to i nepeněžní,

- Rozšíření účasti zaměstnanců na veřejném zdravotním pojištění se stalo kontraproduktivním krokem za předpokladu, že dlouhodobým cílem i nadále zůstává integrace $\mathrm{z}$ př́ijmů fyzických osob a pojistného sociálního pojištění,

- Zavedení všeobecného maximálního vyměřovacího základu na tak vysoké úrovni, že se týká spíše podniků ve vlastnictví fyzických osob než zaměstnanců.

Období let 2009 a 2010 a dále - Modernizace daňového systému (nové zákony o př́mých danich)

Tato fáze daňové reformy je víceméně dosud neujasněná. Na proklamovaných cílech je ale zajímavé, že v řadě př́ípadů její cíle jsou proti cílům daňové reformy z roku 1993.

Základní cíle lze shrnout takto:

- Zjednodušení a zefektivnění daňové správy je pravděpodobně trvalým cílem reforem, vždyt' v této oblasti je stále, co vylepšovat. Nově jde rovněž o elektronizaci daňové správy,

- Nová koncepce prímých daní,

- Sloučení daně z př́jimů fyzických osob a pojistného na sociální zabezpečení by bylo do značné míry návratem před rok $1993 .{ }^{6}$

\section{Vývoj daňového mixu}

Nejprve je důležité vysvětlit, co v podstatě termín daňový mix znamená. Jedná se o jednotlivé daně a kvazidaně používané v dané zemi. Každý moderní daňový systém chce mít rozložení

6 VANČUROVÁ, A. Daňové reformy ČR. Dostupné na WW: <http://www.kdpcr.cz/Data/files/pdf/vancurova.pdf>. [online]. [cit. 2011-05-06]. 
daňového mixu co nejefektivnější. Ukazatel daňového mixu je podíl výkonu jednotlivých daní na celkových daňových př́ijmech. Na následujících grafech bude tento ukazatel posléze ilustrován graficky.

Co se týče České republiky, mezi největší změny, které potkaly zavádění systému daní určitě, patří zavedení daně $\mathrm{z}$ přidané hodnoty $(\mathrm{DPH})^{7}$ a také dvou důchodových daní. Z minulosti je patrné, že mezi důležitá hlediska patřila mimo jiné - obnovení sociálního pojistného jako samostatného př́ijmu veřejných rozpočtů a také zajištění požadavku ze strany Evropské unie na postupné snižování zdanění důchodů (především právnických osob) ${ }^{8}$ a zvyšování podílu nepř́ímých daní (tj. daně ze spotřeby), jak uvádějí R. Baldwin a Ch. Wyplosz. ${ }^{9}$

Jednotlivý vývoj daňového mixu České republiky po těchto změnách je možno ilustrovat na následující tabulce a grafu.

Tabulka 1 Daňové př́íjmy vládního sektoru v období roku 1993 - 2010 (v mld. Kč)

\begin{tabular}{|l|c|c|c|c|c|c|c|c|c|c|}
\hline $\begin{array}{l}\text { Daňové } \\
\text { př́ijmy }\end{array}$ & $\mathbf{1 9 9 3}$ & $\mathbf{1 9 9 4}$ & $\mathbf{1 9 9 5}$ & $\mathbf{1 9 9 6}$ & $\mathbf{1 9 9 7}$ & $\mathbf{1 9 9 8}$ & $\mathbf{1 9 9 9}$ & $\mathbf{2 0 0 0}$ & $\mathbf{2 0 0 1}$ & $\mathbf{2 0 0 2}$ \\
\hline $\begin{array}{l}\text { Daně na } \\
\text { zboží a } \\
\text { služby }\end{array}$ & 137,8 & 154,9 & 173,6 & 196,2 & 211,3 & 216,5 & 240,3 & 247,6 & 255,5 & 265,4 \\
\hline $\begin{array}{l}\text { Pojistné na } \\
\text { ZP a SP }\end{array}$ & 132,1 & 162,3 & 192,5 & 222,2 & 246,8 & 263,1 & 271,3 & 287,4 & 318,9 & 335,0 \\
\hline DzPFO & 29,7 & 54,5 & 68,6 & 80,5 & 87,9 & 94,9 & 95,3 & 98,3 & 104,4 & 114,4 \\
\hline DzPPO & 70,9 & 63,8 & 66,5 & 61,8 & 55,6 & 67,6 & 70,1 & 75,8 & 92,0 & 105,7 \\
\hline $\begin{array}{l}\text { Daně } \\
\text { z majetku a } \\
\text { ostatní daně }\end{array}$ & 22,5 & 10,5 & 10,0 & 8,1 & 9,1 & 10,5 & 11,2 & 12,1 & 11,2 & 12,6 \\
\hline Celkem & $\mathbf{3 9 3 , 0}$ & $\mathbf{4 4 6 , 0}$ & $\mathbf{5 1 1 , 2}$ & $\mathbf{5 6 8 , 8}$ & $\mathbf{6 1 0 , 7}$ & $\mathbf{6 5 2 , 6}$ & $\mathbf{6 8 8 , 2}$ & $\mathbf{7 2 1 , 2}$ & $\mathbf{7 8 2 , 0}$ & $\mathbf{8 3 3 , 1}$ \\
\hline
\end{tabular}

Pramen: Daňové př́ijmy vládního sektoru v období roku 1993 - 2010 (v mld. Kč). Vlastní zpracování na základě dat získaných z WWW: <http://www.mfcr.cz/cps/rde/xbcr/mfcr/FiskalniVyhled_201105_tabulky_grafy_xls.xls>; 〈http://www.mfcr.cz/cps/rde/xchg/mfcr/xsl/makro_pre_10303.html>. [online]. [cit. 2011-05-17].

\footnotetext{
${ }^{7}$ Do konce roku 1992 byla v bývalé Československé federativní republice uplatňována na zboží daň z obratu. Daň z obratu představovala daň určenou procentuálně z ceny obratu zboží při jeho převodu mezi obchodníky. Tím docházelo $\mathrm{k}$ tomu, došlo-li vícekrát $\mathrm{k}$ převodu zboží mezi obchodníky, docházelo $\mathrm{k}$ několika zdaněním.

Od roku 1993, kdy vznikla Česká republika, byla tato daň nahrazena daní z přidané hodnoty, u které dochází ke zdanění pouze "přidané hodnoty", tzn., že dani podléhá pouze hodnota přidaná zpracováním u druhého, třetího či dalšího výrobce (prodejce) a již se nedaní vstupy. Zavedení DPH znamenalo rozšiření zdaňovaných položek také na většinu služeb.

Daň z přidané hodnoty v ČR. Dostupné na WWW: <http://www.finance.cz/zpravy/finance/31843-dan-z-pridanehodnoty-v-cr/>. [online], [cit. 2011-05-25].

${ }^{8}$ Viz §21 Zákona č. 586/1992 Sb., o daních z příjmů, ve znění pozdějších předpisů.

9 Je známý fakt, že jen co se určitá země stane součástí měnové unie, přichází o jeden ze dvou makroekonomických nástrojů - měnovou politiku, zatímco druhý - fiskální politika - nadále zůstává v její kompetenci. Pro fiskální politiku změny ve výdajích anebo daních určují vyrovnanost rozpočtu, což okamžitě vyvolává otázku ohledně financování veřejného dluhu.

Když dojde ke snížení důchodové daně, následkem čehož vzniká rozpočtový deficit. Vláda si bude muset půjčit, čímž dojde ke zvýšení veřejného dluhu, a otázkou je, jak bude zaplacen. Jestliže dojde časem ke zvýšení daní, je opatření správně vnímáno jako snížení daní dnes a jejich zvýšení v budoucnu.
}

BALDWIN, R., WYPLOSZ CH. Ekonomie evropské integrace, s. 421.

\footnotetext{
${ }^{10}$ Daně na zboží a služby = Spotřební daně + Daň z přidané hodnoty (DPH je v souladu s metodikou GFS 2001 snižená o odvod do rozpočtu EU).
} 
Pokračování Tabulky 1 Daňové př́ijmy vládního sektoru v období roku 1993 - 2010 (v mld. Kč)

\begin{tabular}{|l|c|c|c|c|c|c|c|c|}
\hline $\begin{array}{l}\text { Daňové } \\
\text { př́ijmy }\end{array}$ & $\mathbf{2 0 0 3}$ & $\mathbf{2 0 0 4}$ & $\mathbf{2 0 0 5}$ & $\mathbf{2 0 0 6}$ & $\mathbf{2 0 0 7}$ & $\mathbf{2 0 0 8}$ & $\mathbf{2 0 0 9}$ & $\mathbf{2 0 1 0}$ \\
\hline $\begin{array}{l}\text { Daně na } \\
\text { zboží a } \\
\text { služby }\end{array}$ & 282,1 & 306,0 & 343,3 & 376,0 & 393,0 & 396,0 & 391,0 & 413,0 \\
\hline $\begin{array}{l}\text { Pojistné na } \\
\text { ZP a SP }\end{array}$ & 359,7 & 388,3 & 416,1 & 437,0 & 468,0 & 530,0 & 496,0 & 503,0 \\
\hline DzPFO & 123,0 & 133,3 & 142,8 & 137,0 & 144,0 & 143,0 & 128,0 & 131,0 \\
\hline DzPPO & 115,9 & 119,8 & 144,8 & 157,0 & 157,0 & 188,0 & 127,0 & 130,0 \\
\hline $\begin{array}{l}\text { Daně } \\
\text { z majetku a } \\
\text { ostatní daně }\end{array}$ & 14,0 & 15,6 & 13,3 & 14,0 & 15,0 & 16,0 & 14,0 & 16,0 \\
\hline Celkem & $\mathbf{8 9 4 , 7}$ & $\mathbf{9 6 3 , 0}$ & $\mathbf{1 0 6 0 , 3}$ & $\mathbf{1 1 2 1 , 0}$ & $\mathbf{1 1 7 7 , 0}$ & $\mathbf{1 2 7 3 , 0}$ & $\mathbf{1 1 5 6 , 0}$ & $\mathbf{1 1 9 3 , 0}$ \\
\hline
\end{tabular}

Pramen: Daňové příjmy vládního sektoru v období roku 1993 - 2010 (v mld. Kč). Vlastní zpracování na základě dat získaných $\quad \mathrm{z} \quad$ WWW: <http://www.mfcr.cz/cps/rde/xbcr/mfcr/FiskalniVyhled_201105_tabulky_grafy_xls.xls>; <http://www.mfcr.cz/cps/rde/xchg/mfcr/xsl/makro_pre_10303.html>. [online]. [cit. 2011-05-17].

Na základě komparace dat v jednotlivých letech je evidentní, že podíly př́ijmů z daní mají vzrůstající tendenci během těchto osmnácti roků. At' se jedná o daně na zboží a služby, či pojistné na zdravotní a sociální pojištění, nebo daně z prŕíjmů fyzických, právnických osob, daní z majetku a ostatní, každá z nich proporcionálně roste. Teoreticky bychom se měli mít lépe - více vybraných peněz by měl zajistit blahobyt, rozvoj a další pozitivní jistoty. Ale jak již bylo řečeno výše, náš stát se spíše potýká s opačnými problémy. Dalo by se říci, že role státu v sociální oblasti neustále v minulosti narůstala a víceméně drží tuto pozici pořád silnou i nyní. Úspěšně se budují první velmi drahé, sociálně blahobytné státy, zejména v EU. To všechno ale stojí spoustu peněz, a daní - těch není nikdy dost.

Graf 3 Daňové př́ijmy vládního sektoru v období roku 1993 - 2010 (v mld. Kč)

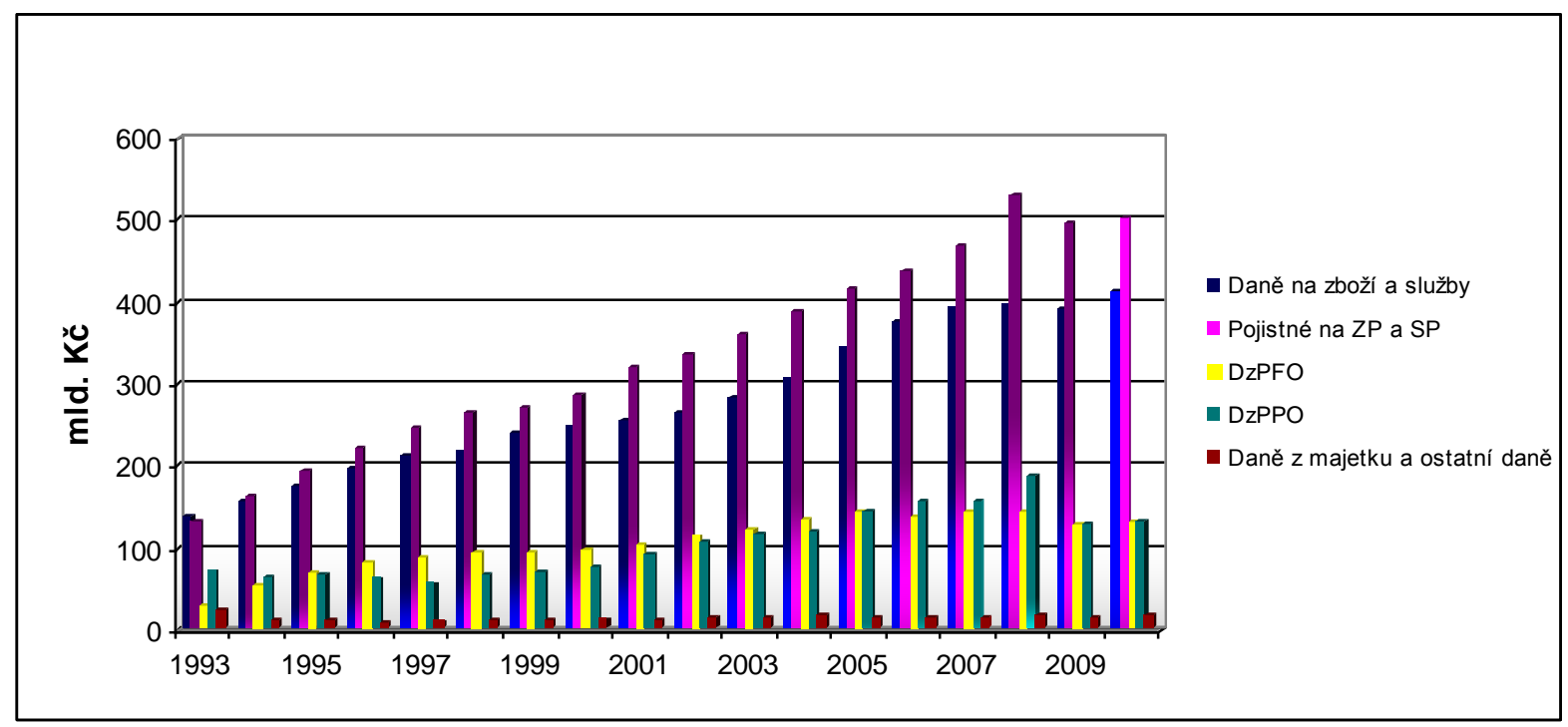

Pramen: Daňové př́ijmy vládního sektoru v období roku 1993 - 2010 (v mld. Kč). Vlastní zpracování na základě dat získaných z $\quad$ WWW: <http://www.mfcr.cz/cps/rde/xbcr/mfcr/FiskalniVyhled_2011-

\footnotetext{
${ }^{11}$ Daně na zboží a služby = Spotřební daně + Daň z přidané hodnoty (DPH je v souladu s metodikou GFS 2001 snižená o odvod do rozpočtu EU).
} 
05_tabulky_grafy_xls.xls>; <http://www.mfcr.cz/cps/rde/xchg/mfcr/xsl/makro_pre_10303.html >. [online]. [cit. 2011-06-04].

V kontextu vývoje lze vidět z předchozí tabulky i grafu, daňové příjmy mají vzrůstající tendenci. Nejvýraznější nárůst dosáhlo pojistné na zdravotní a sociální pojištění (viz rok 2008, kdy dosáhlo vrcholu 530 mld. Kč).

Co se týká daní na zboží a služby, které obsahují spotřební daně a DPH, jejich podíl se neustále zvyšuje, což koresponduje s politikou Evropské unie, takže je v podstatě velmi žádaný. Zase na druhou stranu je nutno podotknout, že tyto zvyšující se odvody sociálního pojištění nejsou pozitivním fenoménem, jelikož čerpání finančních prostředků každoročně převažuje vybrané povinné odvody v této oblasti.

\section{Závěr}

Tento článek se zabýval vývojem daňové politiky a daňového mixu v České republice. Nejprve zdůraznil význam jednotlivých pojmů, jako jsou daňová politika, daňový systém pro ekonomickou realitu, jak ji známe dnes. Celkově článek může mít př́nos pro praxi zejména pro profesní organizace, taktéž prínos pedagogický pro studenty vysokých škol ekonomického zaměření.

Vývoj státního dluhu při pohledu do nedávné minulosti jasně ukazuje růst zapříčiněný neadekvátní hospodářskou politikou, ale také převzetím dluhu při dělení Československa v devadesátých letech minulého století. Následně bylo také ukázáno, jak se plnil státní rozpočet $\mathrm{v}$ minulém roce ve skladbě daňových př́ijmů. Největší podíl na daňových př́imech měla daň z přidané hodnoty, následovaly spotřební daně, za nimi daně z prŕíjmů fyzických i právnických osob a poslední byly ostatní daňové př́ijmy.

Je nutné vyzdvihnout historii daňových reforem v České republice v průběhu cca dvaceti letech, resp. po vzniku České republiky. Za zmínku stojí léta 2007 a 2008, které jsou známé pro svůj charakter ohledně konsolidací veřejných financí. Tyto revoluční roky nastartovaly modernizaci daňového systému, která ve své podstatě stále probíhá.

Jednotlivý vývoj daňového mixu patřičně ukázal, že podíly př́immů z daní mají vzrůstající tendenci, at' už se jedná o daně na zboží a služby, či pojistné na sociální a zdravotní pojištění. Požadavek Evropské unie je, aby se snižovalo zdanění důchodů, především právnických osob a zvyšoval se podíl nepř́mých daní, což se ve své podstatě v podmínkách naší republiky plní.

Co se týče vlastních návrhů, Česká republika se dlouhodobě potýká s komplikovaností a velkou nákladností daňového systému. Důvod je takový, že daní je mnoho, obsahují plno výjimek, úlev. Proto jedním z možných řešení by mohlo být celkové zjednodušení. Rovněž náš stát trápí delší dobu daňové úniky a nedoplatky. Východiskem by mohlo být k přiklonění se k jedné ze zvažovaných variant, jak snížit daňové úniky a zároveň zvýšit př́ijmy do státní pokladny, je uvalit povinnost platit daňový paušál na vybrané profese. Jelikož právě drobné služby jsou totiž živnou půdou pro šedou ekonomiku a daňové úniky, na nichž státní pokladna přichází o desítky miliard korun ročně.

At' už vývoj daňové politiky, či daňového systému bude $\mathrm{v}$ budoucnu jakýkoliv - nikdy nepřestane hrát jednu z klíčových rolí v životě každého občana této země. 


\section{Literatura:}

[1] BALDWIN, R., WYPLOSZ CH. Ekonomie evropské integrace. Praha: Grada Publishing. 2008. 2. vyd., s. 478. ISBN 978-80-247-1807-1.

[2] JANOUŠKOVÁ, J. Daně a daňová politika. Karviná: SU OPF, 2011, 135 s. ISBN 978-80-7248-653-3.

[3] KUBÍČEK, J. A KOL Hospodářská politika. Plzeň: Vydavatelství a nakladatelství Aleš Čeněk, s.r.o., 2006. 302 s. ISBN 80-86898-99-7.

[4] VANČUROVÁ, A. Daňové reformy ČR In. Teoretické a praktické aspekty veřejných financi. VŠE Praha. 2008. ISBN 978-80-245-1378-2.

[5] VANČUROVÁ, A. Daňové reformy ČR. Dostupné na WWW: <http://www.kdpcr.cz/ Data/files/pdf/vancurova.pdf $>$. [online]. [cit. 2011-05-06].

[6] Zákon č. 586/1992 Sb., o daních z př́imů, ve znění pozdějších předpisů.

[7] Vývoj státního dluhu (v mld.). Vlastní zpracování na základě dat získaných z WWW: $<$ http://www.mfcr.cz/cps/rde/xchg/mfcr/xsl/str_vyvoj_sd.html>. [online]. [cit. 2011-0420].

[8] Eurostat. Dostupné na WWW: <http://epp.eurostat.ec.europa.eu>. [online]. [cit. 201104-22].

[9] Podíl jednotlivých daní na daňových př́ijmech státního rozpočtu v roce 2010. Vlastní zpracování na základě dat získaných z WWW:

<http://www.mfcr.cz/cps/rde/xchg/mfcr/xsl/statni_zav_ucet_62819.html?year=PRESEN T>. [online]. [cit. 2011-04-29].

[10] Daňová soustava ČR. Vlastní zpracování na základě informací získaných z WWW: <http://www.mfcr.cz/cps/rde/xchg/ mfcr/xsl/zakony.html>. [online]. [cit. 2011-05-01].

[11] OECD. Dostupné na WWW: <http://www.mfcr.cz/cps/rde/xchg/mfcr/xsl/meo_oecd.html >.[online]. [cit. 2011-05-04].

[12] Daňové př́ijmy vládního sektoru v období roku 1993 - 2010 (v mld. Kč). Vlastní zpracování na základě dat získaných z WWW:

<http://www.mfcr.cz/cps/rde/xbcr/mfcr/FiskalniVyhled_2011-

05_tabulky_grafy_xls.xls>. [online]. [cit. 2011-05-17].

[13] Daňové př́íjmy vládního sektoru v období roku 1993 - 2010 (v mld. Kč). Vlastní zpracování na základě dat získaných z WWW:

<http://www.mfcr.cz/cps/rde/xchg/mfcr/xsl/makro_pre_10303.html>. [online]. [cit. 2011-05-17].

[14] Daň z přidané hodnoty v ČR. Dostupné na WWW:

<http://www.finance.cz/zpravy/finance/31843-dan-z-pridane-hodnoty-v-cr/>. [online], [cit. 2011-05-25]

Klasifikace JEL: E20, E60, E64

\section{Ing. Monika Pavlíková}

studentka doktorského studia

Katedra účetnictví

Obchodně podnikatelská fakulta

Slezská univerzita

Univerzitní náměstí 1934/3, 73340 Karviná

pavlikova@opf.slu.cz 